\title{
Potensi timbulan sampah plastik di Kota Yogyakarta tahun 2035
}

\section{Tiaranita Yusari*, Joni Purwohandoyo*}

* Program Studi Pembangunan Wilayah, Fakultas Geografi, Universitas Gadjah Mada, Indonesia

\begin{tabular}{l}
\hline \hline ARTICLES INFO \\
\hline Profil Articles: \\
Sent: 7-9-2019 \\
Approved: 4-3-2020 \\
Published: 30-6-2020 \\
\hline
\end{tabular}

\section{Key words:}

Sampah; plastik;

timbulan; potensi

\section{Correspondent Author:}

Tiaranita Yusari

Program Studi Pembangunan Wilayah

Universitas Gadjah Mada

Bulaksumur, Depok, Sleman, D.I. Yogyakarta 55821

E-mail: tiarantysr@gmail.com

Plastic waste is the center of attention in urban areas in Indonesia, one of them is Yogyakarta. Yogyakarta is the largest wastes supplier in Piyungan's Integrated Waste Management Site. Piyungan decreases every year. Therefore, Yogyakarta Government must take appropriate steps to obtain waste generation in the future. This research aims to make a projection of plastic waste generation in Yogyakarta in 2035. The result of this research reveal the generation of plastic waste in Yogyakarta in 2035 based on the standard capacity of each region and pattern of the distribution of plastic waste in each block of the desired area.

Sampah plastik merupakan permasalahan yang menjadi pusat perhatian di perkotaan di Indonesia, salah satunya adalah Kota Yogyakarta. Kota Yogyakarta merupakan pemasok sampah terbesar di TPST (Tempat Pengelolaan Sampah Terpadu) Piyungan. Padahal kemampuan daya tampung TPST Piyungan semakin berkurang setiap tahunnya. Oleh karena itu, Pemerintah Kota Yogyakarta harus mengambil langkah yang tepat untuk mengantisipasi tingginya timbulan sampah di masa mendatang. Penelitian ini bertujuan untuk memproyeksikan timbulan sampah plastik di Kota Yogyakarta pada tahun 2035. Pendekatan yang digunakan adalah pendekatan kuantitatif dengan data berupa populasi 45 blok kawasan perencanaan Kota Yogyakarta. Hasil dari penelitian ini menunjukkan perkiraan timbulan sampah plastik di Kota Yogyakarta tahun 2035 berdasarkan standar daya tampung orang setiap kawasan serta pola sebaran timbulan sampah plastik pada masing-masing blok kawasan yang bersangkutan.

This is an open access article under the CC-BY-SA license

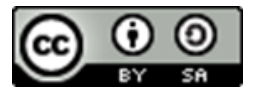

\section{PENDAHULUAN}

Sampah plastik merupakan permasalahan yang cukup menjadi sorotan di berbagai wilayah perkotaan di Indonesia bahkan di dunia. (Ekawati, 2016) dalam penelitiannya menyatakan bahwa kota-kota di dunia memiliki potensi menghasilkan sampah plastik mencapai 1,3 miliar ton per tahun. Padahal, sampah plastik memiliki sifat yang sulit terurai sehingga membahayakan kelestarian lingkungan apabila sampah plastik tidak mengalami pengelolaan yang baik. 
Jurnal Pendidikan Geografi:

Kajian, Teori, dan Praktik dalam Bidang Pendidikan dan Ilmu Geografi

Volume 25, Nomor 2, Jun 2020, Hal 88-101

Kondisi timbulan sampah juga rentan terjadi di Indonesia mengingat Indonesia merupakan negara kepulauan. (Jambeck et al., 2015) mengatakan bahwa Indonesia berada pada posisi kedua tertinggi di dunia setelah Cina sebagai penghasil sampah plastik. Indonesia adalah negara penghasil limbah plastik kedua terbesar di dunia setelah Cina, yakni sekitar 3,2 juta metrik ton per tahun (Jambeck et al., 2015). Sebuah riset dari organisasi nonpemerintahan "Greeneration", menyebutkan bahwa setiap tahun di Indonesia rata- rata setiap orang dapat menghasilkan 700 kantong sampah plastik per tahun. Berdasarkan asumsi Kementerian Lingkungan Hidup (KLH), setiap hari penduduk Indonesia menghasilkan 0,8 kilogram sampah per orang atau secara total sebanyak 189 ribu ton sampah per hari. Dari jumlah tersebut, 15 persen berupa sampah plastik atau sejumlah 28,4 ribu ton sampah plastik per hari (Surono dan Ismanto, 2016). Kondisi ini menjadi sebuah permasalahan besar bagi Indonesia.

Jumlah timbulan sampah plastik diperkirakan akan terus meningkat karena adanya kebutuhan atau pola konsumsi masyarakat yang juga meningkat. Kondisi inipun cukup krusial terjadi di Kota Yogyakarta. Berdasarkan data TPST (Tempat Pengelolaan Sampah Terpadu) Piyungan, Kota Yogyakarta merupakan pemasok sampah terbesar ke TPST Piyungan. Pernyataan tersebut juga didukung pernyataan bahwa setiap orang di Kota Yogyakarta memiliki potensi menghasilkan sampah sebanyak 900 gram setiap harinya (Mulasari et al., 2016).

Permasalahan sampah plastik menjadi masalah yang serius dan krusial, terutama bagi kota-kota besar di Indonesia, salah satunya adalah Kota Yogyakarta. Kota Yogyakarta merupakan wilayah pemasok sampah terbesar di TPST Piyungan di antara Kabupaten Sleman dan Kabupaten Bantul. Data ini diperoleh dari pengelola TPST Piyungan mengenai data timbangan sampah di TPST Piyungan. Kondisi ini disebabkan oleh kompleksitas kegiatan yang terjadi di Kota Yogyakarta yang berpotensi sebagai sumber penghasil limbah berupa sampah plastik. Kondisi tersebut juga akan mengalami peningkatan ketika musim-musim tertentu, seperti musim liburan. Padahal TPST Piyungan akan mengalami penurunan kapasitas daya tampung sampah seiring berjalannya waktu. Oleh karena itu, Pemerintah Kota Yogyakarta harus melakukan penanganan tertentu dalam mengantisipasi kemungkinan tingginya timbulan sampah plastik di Kota Yogyakarta di masa mendatang.

Plastik yang telah menjadi sampah bersifat tidak biodegradable sehingga dapat berdampak negatif terhadap lingkungan (Surono dan Ismanto, 2016). Antisipasi terkait dampak dari tingginya timbulan sampah dapat diawali dengan melalui proyeksi mengenai potensi timbulan sampah plastik di Kota Yogyakarta di waktu mendatang. Penelitian ini melakukan proyeksi timbulan sampah plastik di Kota Yogyakarta pada tahun 2035. Proyeksi dilakukan untuk tahun 2035 karena menyesuaikan rencana perkembangan perkotaan yang telah dimuat dalam Rencana Detail Tata Ruang (RDTR) Kota Yogyakarta Tahun 2015-2035 (Perda, 2015).

Kajian mengenai sampah plastik ini dikaitkan dengan salah satu pendekatan geografi, yakni pendekatan keruangan. Analisis pendekatan keruangan menekankan eksistensi ruang sebagai variabel utama dalam suatu kajian. Kajian yang membahas mengenai pengelolaan sampah pada umunya membutuhkan studi geografis yang cukup jelas, terutama terkait pola sebaran timbulan sampah itu sendiri (Adedibu, 1985). Namun, penelitian mengenai sampah masih banyak mengabaikan studi geografi terkait dimensi spasial (Rybova dan Burcin, 2017). Padahal studi geografi dalam kajian persampahan dapat memberikan pengetahuan pola spasial mengenai komposisi sampah dan besaran intensitas timbulan sampah dari setiap sumber kegiatan. Penelitian ini bertujuan untuk 
Jurnal Pendidikan Geografi:

Kajian, Teori, dan Praktik dalam Bidang Pendidikan dan Ilmu Geografi

Volume 25, Nomor 2, Jun 2020, Hal 88-101

memproyeksikan timbulan sampah plastik di Kota Yogyakarta pada tahun 2035 dengan melibatkan analisis spasial.

\section{METODE}

Penelitian ini menggunakan pendekatan kuantitatif. Penelitian ini menggunakan data sekunder, yakni data luas 45 blok kawasan yang mengacu pada Rencana Detail Tata Ruang Kota Yogyakarta Tahun 2015- 2035. Data lain yang diperlukan adalah standar timbulan sampah plastik berdasarkan sumbernya dan peta RDTR Kota Yogyakarta. Data sekunder diperoleh dari beberapa instansi terkait dan beberapa literatur lainnya.

Perhitungan proyeksi timbulan sampah plastik tidak menggunakan acuan jumlah penduduk wilayah seperti rumus proyeksi pada umumnya karena hasilnya tidak dapat dipetakan berdasarkan blok kawasan, melainkan hanya secara administratif. Sedangkan idealnya, secara keruangan timbulan sampah yang dihasilkan dari setiap sumber kegiatan memiliki standar yang berbeda-beda (SNI, 2008). Oleh karena itu, perhitungan proyeksi timbulan sampah plastik di Kota Yogyakarta mengacu kepada luasan peruntukan lahan untuk kegiatan-kegiatan tertentu yang direncanakan hingga tahun 2035.Setiap blok kawasan diidentifikasi terlebih dahulu terkait jumlah orang yang ditampung di dalamnya. Standar luas daya tampung per orang untuk masing-masing kawasan (SNI, 2004).

Tabel 1. Matriks Indikator, Variabel, Objek Penelitian, dan Teknik Analisis Data

\begin{tabular}{|c|c|c|c|}
\hline Tujuan Penelitian & Variabel dan Indikator & $\begin{array}{c}\text { Objek } \\
\text { Penelitian }\end{array}$ & $\begin{array}{c}\text { Teknik } \\
\text { Analisis }\end{array}$ \\
\hline $\begin{array}{l}\text { Memproyeksikan } \\
\text { timbulan sampah } \\
\text { plastik di Kota } \\
\text { Yogyakarta tahun } \\
2035\end{array}$ & $\begin{array}{l}\text { 1. Timbulan sampah plastik di Kota Yogyakarta } \\
\text { - } \quad \text { Standar volume timbulan sampah per orang berdasarkan } \\
\text { sumbernya } \\
\text { - } \quad \text { Standar volume timbulan sampah plastik di Kota } \\
\text { Yogyakarta berdasarkan sumbernya }(16,24 \% \text { dari } \\
\text { sampah kawasan permukiman dan } 10,79 \% \text { dari sampah } \\
\text { kawasan nonpermukiman) } \\
\text { - Standar daya tampung kawasan } \\
\text { 2. Sebaran spasial proyeksi timbulan sampah plastik di Kota } \\
\text { Yogyakarta } \\
\text { - Hasil proyeksi timbulan sampah plastik di Kota } \\
\text { - Yogyakarta tahun } 2025 \text { berdasarkan sumbernya } \\
\text { Luas blok kawasan perencanaan berdasarkan RDTR } \\
\text { Kota Yogyakarta tahun 2015-2035 }\end{array}$ & $\begin{array}{c}\text { Populasi } \\
\text { (Seluruh Blok } \\
\text { Kawasan di } \\
\text { Kota } \\
\text { Yogyakarta) }\end{array}$ & $\begin{array}{l}\text { Deskriptif } \\
\text { kuantitatif }\end{array}$ \\
\hline
\end{tabular}

Sumber: Hasil penelusuran peneliti, 2019

Tabel 2. Rumus Perhitungan Proyeksi Timbulan Sampah Plastik

\begin{tabular}{|c|c|}
\hline Keterangan & Rumus \\
\hline Blok & Nama blok \\
\hline Luas Eksisting $\left(\mathrm{m}^{2}\right)$ & a \\
\hline Luas Wilayah (Akhir Tahun Perencanaan: 2035) $\left(\mathrm{m}^{2}\right)$ & $\mathrm{b}$ \\
\hline Kawasan & Nama kawasan \\
\hline Standar Daya Tampung (m²/org) & $\mathrm{c}$ \\
\hline Jumlah Orang & $d=(b / c)$ \\
\hline Standar Timbulan Sampah (liter/org/hr) & e \\
\hline Standar Timbulan Sampah Plastik (\%) & $\mathrm{f}$ \\
\hline Potensi Timbulan Sampah (Asumsi 100\%) (liter/hr) & $g=(d \times e)$ \\
\hline Potensi Timbulan Sampah Plastik (Asumsi 100\%) (liter/hr) & $h=(f \times g)$ \\
\hline
\end{tabular}

Sumber: Hasil penelusuran peneliti, 2019 
Tabel 1 menunjukkan indikator dan variabel yang digunakan untuk melakukan proyeksi timbulan sampah plastik di Kota Yogyakarta. Indikator dan variabel tersebut digunakan untuk menghasilkan angka proyeksi timbulan sampah plastik yang kemudian digunakan untuk mengidentifikasi sebaran timbulan sampah plastik pada masing-masing blok kawasan sebagaimana cara perhitungannya dijelaskan pada Tabel 2. Sebaran potensi timbulan sampah plastik di Kota Yogyakarta tahun 2035 mendatang disajikan dalam bentuk peta. Teknik analisis data yang digunakan dalam penelitian ini adalah deskriptif kuantitatif.

\section{HASIL DAN PEMBAHASAN}

Kota Yogyakarta merupakan ibukota Provinsi DIY, sehingga wilayah tersebut memiliki kegiatan yang kompleks di dalamnya. Berdasarkan Peta Rencana Detail Tata Ruang Kota Yogyakarta Tahun 2015- 2035, ruang di Kota Yogyakarta diarahkan peruntukannya untuk beberapa jenis kegiatan yang terbagi menjadi kawasan-kawasan, diantaranya kawasan cagar budaya, pariwisata, industri, perdagangan dan jasa, perkantoran, perumahan, ruang terbuka hijau, sarana kesehatan, sarana olahraga dan rekreasi, sarana pendidikan, dan sarana transportasi. Sebaran blok kawasan yang telah dituangkan dalam RDTR Kota Yogyakarta Tahun 2015-2035 disajikan pada Gambar 1.

Kegiatan yang bergerak di Kota Yogyakarta memiliki tingkat intensitas yang berbeda-beda. Rencana tata ruang yang yang detail diharapkan mampu menjadi pedoman dalam menentukan arah perkembangan Kota Yogyakarta di masa mendatang. Namun, perkembangan kota yang cukup kompleks juga dapat memberikan dampak bagi lingkungan, salah satunya dapat menyebabkan wilayah tersebut memiliki potensi timbulan sampah dalam volume yang cukup tinggi di masa mendatang. Oleh karena itu, dalam menentukan arah kebijakan dalam mengantisipasi dampak buruk dari perkembangan kota, perlu adanya gambaran proyeksi mengenai potensi limbah yang dihasilkan dari setiap kegiatan yang bergerak di Kota Yogyakarta, khususnya proyeksi timbulan sampah plastik. Hal ini bertujuan agar semua pihak memiliki kesadaran terhadap pemeliharaan lingkungan atas kegiatan yang ada di dalamnya.

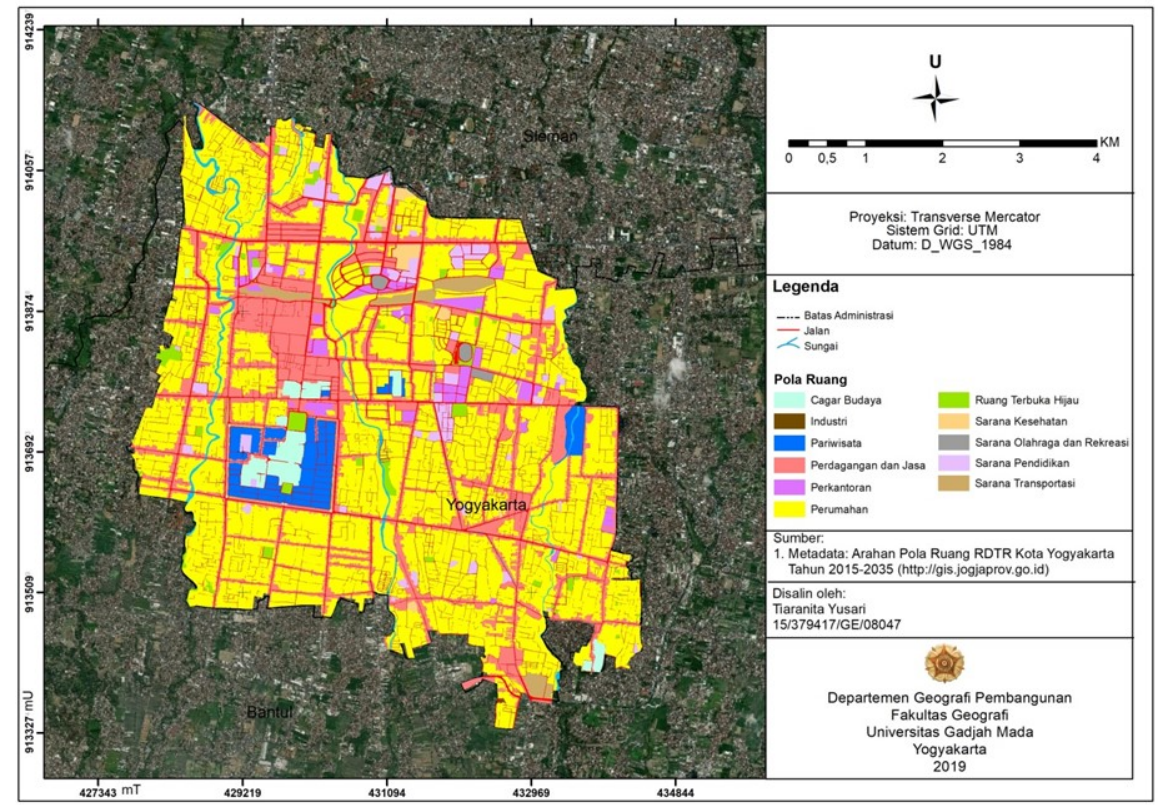

Gambar 1. Peta Rencana Detail Tata Ruang Kota Yogyakarta Tahun 2015-2035 
Jurnal Pendidikan Geografi:

Kajian, Teori, dan Praktik dalam Bidang Pendidikan dan Ilmu Geografi

Volume 25, Nomor 2, Jun 2020, Hal 88-101

Di sisi lain, data hasil survei Dinas Lingkungan Hidup Kota Yogyakarta tahun 2016 yang menunjukkan bahwa Kota Yogyakarta adalah pemasok sampah terbesar ke TPST Piyungan di antara Kabupaten Bantul dan Kabupaten Sleman. Jumlah timbangan sampah dari masing- masing wilayah pelayanan di TPST Piyungan pada tahun 2016 dapat dilihat pada Tabel 3.

Setiap kawasan di Kota Yogyakarta memiliki potensi timbulan sampah yang berbeda-beda. Penelitian ini menggunakan beberapa variabel untuk menghitung proyeksi timbulan sampah plastik, diantaranya luas wilayah yang direncanakan pada tahun mendatang, standar daya tampung luas per orang pada setiap kegiatan dalam tiap kawasan, prediksi jumlah penduduk yang dilayani oleh masing-masing kawasan pada tahun yang direncanakan, dan standar timbulan sampah plastik per hari.

Sumber sampah di Kota Yogyakarta berasal dari kawasan permukiman dan kawasan nonpermukiman. Menurut DLH Kota Yogyakarta, kawasan permukiman meliputi kawasan perumahan. Sedangkan kawasan nonpermukiman meliputi dari fasilitas -fasilitas seperti sekolah, perkantoran, pertokoan, fasilitas kesehatan, pasar, restoran/ rumah makan, hotel, tempat wisata, industri, tempat ibadah, ruas jalan, dan terminal. Dalam perhitungan potensi sampah, sumber sampah dari kawasan permukiman maupun nonpermukiman menurut DLH Kota Yogyakarta disesuaikan dengan kawasan yang direncanakan dalam RDTR Kota Yogyakarta Tahun 2015-2035.

Tabel 3. Timbangan Sampah di TPST Piyungan Tahun 2016

\begin{tabular}{lllllllll}
\hline \multicolumn{1}{c}{ Bulan } & $\begin{array}{c}\text { Kab. } \\
\text { Bantul }\end{array}$ & $\begin{array}{c}\text { Kab. } \\
\text { Sleman }\end{array}$ & $\begin{array}{c}\text { Kota } \\
\text { Yogyakarta }\end{array}$ & $\begin{array}{c}\text { Swasta } \\
\text { Kab. } \\
\text { Bantul }\end{array}$ & $\begin{array}{c}\text { Swasta } \\
\text { Kab. } \\
\text { Sleman }\end{array}$ & $\begin{array}{c}\text { Swasta } \\
\text { Kota }\end{array}$ & Insidental & $\begin{array}{c}\text { Jumlah } \\
\text { (ton) }\end{array}$ \\
\hline Januari & 1671 & 4701 & 4153 & 149 & 356 & 2693 & 1415 & 15138 \\
Februari & 1733 & 4666 & 4293 & 153 & 367 & 2440 & 2118 & 15770 \\
Maret & 1914 & 4970 & 4336 & 109 & 390 & 2621 & 2192 & 16532 \\
April & 1502 & 4218 & 2350 & 54 & 322 & 2510 & 1714 & 12670 \\
Mei & 1327 & 4273 & 4080 & 71 & 306 & 147 & 2075 & 12279 \\
Juni & 1561 & 4293 & 5145 & 59 & 274 & 24 & 2367 & 13723 \\
Juli & 1630 & 4022 & 6193 & 66 & 207 & 22 & 2459 & 14599 \\
Agustus & 1817 & 4590 & 6586 & 69 & 274 & 20 & 2935 & 16291 \\
September & 1633 & 4341 & 6085 & 40 & 263 & 23 & 2460 & 14845 \\
Oktober & 2081 & 4994 & 7066 & 55 & 309 & 28 & 2743 & 17276 \\
November & 2196 & 5007 & 7007 & 44 & 324 & 224 & 2907 & 17709 \\
Desember & 2271 & 4945 & 7105 & 64 & 271 & 261 & 1291 & 16208 \\
Total (ton) & 21336 & 55010 & 64399 & 933 & 3663 & 11013 & 26676 & 183040 \\
\hline Rata-Rata & 1778 & 4585 & 5367 & 78 & 305 & 918 & 2223 & 15253 \\
\hline
\end{tabular}

Tabel 4. Standar Timbulan Sampah berdasarkan Sumbernya

\begin{tabular}{ll}
\hline \multicolumn{1}{c}{ Sumber } & \multicolumn{1}{c}{ Besaran Timbulan Sampah } \\
\hline Rumah permanen & $2,5 \mathrm{~L} / \mathrm{org} / \mathrm{hr}$ \\
Rumah semi permanen & $2,25 \mathrm{~L} / \mathrm{org} / \mathrm{hr}$ \\
Rumah non permanen & $2 \mathrm{~L} / \mathrm{org} / \mathrm{hr}$ \\
Kantor & $0,75 \mathrm{~L} / \mathrm{pgw} / \mathrm{hr}$ \\
Toko/ruko/perdagangan dan jasa & $3 \mathrm{~L} / \mathrm{ptgs} / \mathrm{hr}$ \\
Sarana pendidikan (sekolah) & $0,15 \mathrm{~L} / \mathrm{mrd} / \mathrm{hr}$ \\
Industri (Asumsi standar timbulan sampah kota sedang/kecil) & $2,5 \mathrm{~L} / \mathrm{org} / \mathrm{hr}$ \\
Sarana olahraga dan rekreasi (asumsi standar timbulan sampah kota sedang/kecil) & $2,5 \mathrm{~L} / \mathrm{org} / \mathrm{hr}$ \\
Sarana transportasi (asumsi standar timbulan sampah kota sedang/kecil) & $2,5 \mathrm{~L} / \mathrm{org} / \mathrm{hr}$ \\
Cagar budaya (asumsi standar timbulan sampah kota sedang/kecil) & $2,5 \mathrm{~L} / \mathrm{org} / \mathrm{hr}$ \\
Pariwisata (asumsi standar timbulan sampah kota sedang/kecil) & $2,5 \mathrm{~L} / \mathrm{org} / \mathrm{hr}$ \\
\hline
\end{tabular}

Sumber: Standar Besaran Timbulan Sampah menurut SNI-3242-2008 
Jurnal Pendidikan Geografi:

Kajian, Teori, dan Praktik dalam Bidang Pendidikan dan Ilmu Geografi

Volume 25, Nomor 2, Jun 2020, Hal 88-101

Hasil penyesuaiaan menunjukkan sumber timbulan sampah di Kota Yogyakarta meliputi diantaranya kawasan perumahan, perdagangan dan jasa, perkantoran, sarana transportasi, sarana pendidikan, sarana kesehatan, industri, sarana olahraga dan rekreasi, cagar budaya, pariwisata, dan ruang terbuka hijau. Timbulan sampah yang dihasilkan dari setiap kawasan tersebut berbeda-beda. Standar rata-rata volume timbulan sampah setiap kawasan dalam penelitian ini menggunakan standar yang tercantum dalam SNI3242-2008.

Tabel 4 menunjukkan standar besaran timbulan sampah pada masing-masing sumbernya. Satuan besaran timbulan sampah menggunakan satuan L/orang/hari. Untuk menghitung potensi timbulan sampah pada setiap blok kawasan membutuhkan data jumlah penduduk yang berkegiatan pada kawasan yang bersangkutan. Identifikasi banyaknya penduduk yang berkegiatan di masing-masing kawasan dapat dilakukan dengan membandingkan luas kawasan dengan standar daya tampung orang pada tiap kawasan. Luas kawasan pada masing-masing blok diidentifikasi melalui peta RDTR Kota Yogyakarta Tahun 2015-2035 yang dikalibrasikan dengan luas yang dicantumkan dalam Peraturan Daerah Kota Yogyakarta No. 1 Tahun 2015 tentang Rencana Detail Tata Ruang Kota Yogyakarta Tahun 2015-2035. Luas kawasan yang direncanakan yang dibandingkan dengan standar daya tampung orang akan menghasilkan prediksi jumlah orang yang akan ditampung dalam suatu fasilitas kegiatan.

Tabel 5 menunjukkan standar luas daya tampung per orang pada masing-masing kawasan. Standar tersebut telah dirumuskan dalam SNI 03-1733-2004. Luas kawasan pada masing-masing blok perencanaan yang dibandingkan dengan standar luas daya tampung per orang pada tiap kawasan akan menghasilkan kemungkinan jumlah orang yang dapat ditampung pada masing-masing kawasan setiap blok perencanaan hingga tahun 2035 mendatang. Proyeksi jumlah orang yang ditampung pada masing-masing blok kawasan diasumsikan sebagai jumlah orang yang akan menghasilkan limbah berupa sampah plastik dari kegiatan yang bergerak pada tiap kawasan. Angka proyeksi jumlah orang yang ditampung tersebut digunakan sebagai faktor pengali dengan standar besaran timbulan sampah berdasarkan sumbernya seperti yang telah diuraikan pada Tabel 4 . Hasilnya adalah berupa proyeksi timbulan sampah pada setiap blok kawasan pada tahun 2035.

Proyeksi timbulan sampah khusus jenis plastik diasumsikan berdasarkan hasil survei Dinas Lingkungan Hidup Kota Yogyakarta mengenai timbulan sampah di Kota Yogyakarta pada tahun 2017 seperti yang telah diuraikan pada Tabel 6.

Tabel 5. Standar Daya Tampung Kawasan

\begin{tabular}{|c|c|}
\hline Kawasan & Standar Daya Tampung $\left(\mathrm{m}^{2} / \mathrm{org}\right)$ \\
\hline Perumahan & 9,6 \\
\hline Perdagangan dan Jasa & 0,5 \\
\hline Ruang Terbuka Hijau & 0,3 \\
\hline Sarana Pendidikan & 2,6 \\
\hline Industri & 0,5 \\
\hline Perkantoran & 0,12 \\
\hline Sarana Olahraga dan Rekreasi & 0,3 \\
\hline Saran Transportasi & 0,12 \\
\hline Cagar Budaya & 0,12 \\
\hline Pariwisata & 0,12 \\
\hline
\end{tabular}

Sumber: SNI 03-1733-2004 tentang Tata Cara Perencanaan Lingkungan Perumahan di Perkotaan 
Jurnal Pendidikan Geografi:

Kajian, Teori, dan Praktik dalam Bidang Pendidikan dan Ilmu Geografi

Volume 25, Nomor 2, Jun 2020, Hal 88-101

Hasil survei tersebut menunjukkan bahwa 10,79 persen dari total sampah permukiman merupakan sampah berjenis plastik untuk kawasan perumahan. Sedangkan 16,24 persen dari total sampah nonpermukiman merupakan sampah berjenis plastik untuk kawasan nonpermukiman. Standar tersebut digunakan sebagai acuan dalam menghitung proyeksi timbulan sampah plastik dari setiap blok kawasan di Kota Yogyakarta pada tahun 2035 mendatang.

Kota Yogyakarta terbaik menjadi 14 kecamatan yang didalamnya memiliki arahan peruntukan lahan yang berbeda-beda. Arahan peruntukan lahan tersebut akan menciptakan kegiatan-kegiatan yang memiliki intensitas tertentu dan menjadikan Kota Yogyakarta sebagai wilayah dengan kompleksitas kegiatan yang cukup tinggi. Kondisi tersebutlah yang kemudian memicu adanya produksi sampah, salah satunya sampah plastik setiap hari. jumlah timbulan sampah plastik diprediksikan akan semakin meningkat setiap tahunnya karena adanya peningkatan dan perkembangan kegiatan yang bergerak pada masing-masing kawasan di Kota Yogyakarta.

Timbulan sampah plastik di Kota Yogyakarta diproyeksi dengan beberapa asumsi. Asumsi tersebut dilakukan atas dasar kemungkinan realisasi perencanaan yang dirumuskan dalam RDTR Kota Yogyakarta Tahun 2015-2035. Peneliti mengasumsikan adanya kemungkinan realisasi perencanaan sebesar 60 persen, 70 persen, 80 persen, 90 persen, dan 100 persen. Maksud dari asumsi 60 persen adalah perencanaan blok kawasan dalam RDTR Kota Yogyakarta diprediksikan hanya terealisasi sebesar 60 persen dari rencana yang bersangkutan hingga tahun 2035 mendatang. Begitu pula dengan asumsi lainnya, misalnya asumsi 100 persen adalah prediksi terhadap rencana yang akan terealisasi sepenuhnya hingga tahun 2035 mendatang.

Tabel 7 menunjukkan nilai potensi timbulan sampah plastik di Kota Yogyakarta pada tahun 2035 dengan beberapa asumsi realisasi perencanaan. Potensi timbulan sampah plastik apabila rencana blok kawasan di Kota Yogyakarta terealisasi 100 persen hingga tahun 2035 adalah sebesar 16.504.985,03 liter/hari. Sedangkan asumsi realisasi 90 persen menghasilkan potensi timbulan sebesar $14.864 .116,77$ liter/hari, asumsi realisasi 80 persen menghasilkan potensi timbulan sebesar 13.100.380,76 liter/hari, asumsi realisasi 70 persen menghasilkan potensi timbulan sebesar $11.560 .979,71$ liter/ hari, dan asumsi realisasi 60 persen menghasilkan potensi timbulan sebesar 9.909.411,18 liter/hari.

Tabel 6. Standar Timbulan Sampah Plastik

\begin{tabular}{ccc}
\hline No. & Standar Timbulan Sampah Plastik & Sumber \\
\hline 1 & $10,79 \%$ & Sampah kawasan permukiman \\
2 & $16,24 \%$ & Sampah kawasan nonpermukian \\
\hline
\end{tabular}

Sumber: Dinas Lingkungan Hidup Kota Yogyakarta (2017)

Tabel 7. Potensi Timbulan Sampah Plastik di Kota Yogyakarta Tahun 2035

\begin{tabular}{ccc}
\hline No. & Asumsi & Potensi Timbulan Sampah Plastik (liter/hr) \\
\hline 1 & $100 \%$ & $16.504 .985,03$ \\
2 & $90 \%$ & $14.864 .116,77$ \\
3 & $80 \%$ & $13.100 .380,76$ \\
4 & $70 \%$ & $11.560 .979,71$ \\
5 & $60 \%$ & $9.909 .411,18$ \\
\hline
\end{tabular}

Sumber: Data olahan (2019) 
Jurnal Pendidikan Geografi:

Kajian, Teori, dan Praktik dalam Bidang Pendidikan dan Ilmu Geografi

Volume 25, Nomor 2, Jun 2020, Hal 88-101

Nilai potensi timbulan sampah plastik tersebut merupakan total timbulan sampah plastik untuk skala Kota Yogyakarta yang bersumber dari berbagai kawasan pada tiap blok perencanaan. Potensi timbulan tersebut hanya bagian dari 10,79 persen dari total timbulan sampah permukiman dan 16,24 persen dari total timbulan sampah nonpermukiman.

Kawasan yang memiliki timbulan sampah plastik cukup tinggi adalah kawasan perumahan, cagar budaya, pariwisata, dan kawasan perdagangan dan jasa. Timbulan sampah dari kawasan perumahan tersebar di seluruh blok perencanaan di Kota Yogyakarta. Artinya semua blok di Kota Yogyakarta memiliki arahan peruntukan lahannya sebagian untuk kawasan perumahan. Kondisi ini tentunya menunjukkan bahwa terdapat sejumlah penduduk yang bermukim di setiap blok di Kota Yogyakarta. Hal ini menyebabkan timbulan sampah plastik dari kawasan perumahan memiliki potensi yang tinggi apabila diakumulasikan dari setiap blok. Timbulan sampah plastik yang tinggi dari kawasan perumahan juga disebabkan karena pertumbuhan penduduk di Kota Yogyakarta yang semakin meningkatn setiap tahunnya. Kondisi tersebut menyebabkan adanya peningkatan yang terus-menerus terjadi atas kebutuhan lahan untuk bermukim atau bertempat tinggal. Kondisi tersebut juga dapat menjadi salah satu penyebab tingginya timbulan sampah plastik karena tingginya konsumsi rumah tangga yang juga diprediksikan rutin terjadi setiap harinya.

Sampah yang dihasilkan dari kawasan perumahan dapat disebut pula sebagai sampah rumah tangga. Sampah plastik yang berasal dari rumah tangga pada umumnya memiliki potensi untuk dapat didaur ulang. Sampah plastik dari rumah tangga juga memiliki kecenderungan kondisi yang bersih dan kualitas yang cukup baik. Hal ini berlaku apabila pihak rumah tangga terlibat dalam pemilahan sampah yang dilakukan dengan baik. Pemilahan sampah yang baik juga berlaku apabila pihak rumah tangga terlibat dalam proses daur ulang, yakni menjual sampah plastik yang telah dikumpulkan kepada bank sampah. Oleh karena itu, sampah plastik tidak berakhir di tempat sampah, melainkan diproses kembali agar memiliki nilai ekonomi dan mengurangi dampak buruk bagi lingkungan.

Pola sebaran potensi timbulan sampah plastik di Kota Yogyakarta pada tahun 2035 ditunjukkan pada Gambar 2. Gambar 2 merupakan peta pola sebaran potensi timbulan sampah plastik di Kota Yogyakarta pada tahun 2035 dengan asumsi realisasi rencana 60 persen dan asumsi realisasi rencana 100 persen. Pada peta hasil proyeksi asumsi 60 persen dan 100 persen memiliki perbedaan yang terlihat pada warna pola sebaran timbulannya pada beberapa blok kawasan perencanaan. Pola sebaran potensi timbulan sampah plastik di Kota Yogyakarta ada yang bersifat memusat dan ada pula yang bersifat sporadis dan linear mengikut jalan utama di Kota Yogyakarta.

Gambar 2 (A) menunjukkan bahwa potensi timbulan sampah plastik tertinggi terdapat di Blok G1, G2, dan G3. Blok G1 merupakan cakupan wilayah Kelurahan Patehan, Blok G2 merupakan cakupan wilayah Kelurahan Panembahan, dan Blok G3 merupakan cakupan wilayah Kelurahan Kadipaten. Sampah plastik dengan potensi timbulan yang tinggi di ketiga blok tersebut ditunjukkan dengan pola warna coklat muda (timbulan sampah sebanyak 0-200.000) hingga coklat tua pekat (timbulan sampah $>800.000$ ). Timbulan sampah plastik paling tinggi pada Blok G1, G2, dan G3 bersumber dari kawasan pariwisata. Pada kondisi sebenarnya, ketiga wilayah tersebut merupakan pusat destinasi wisata di Kota Yogyakarta. Hal ini ditunjukkan ditunjukkan melalui keberadaan beberapa objek wisata di wilayah tersebut seperti Alun-Alun Kidul, AlunAlun Utara, Kraton Yogyakarta, dan Kampung Wisata Taman Sari. 
Jurnal Pendidikan Geografi:

Kajian, Teori, dan Praktik dalam Bidang Pendidikan dan Ilmu Geografi

Volume 25, Nomor 2, Jun 2020, Hal 88-101

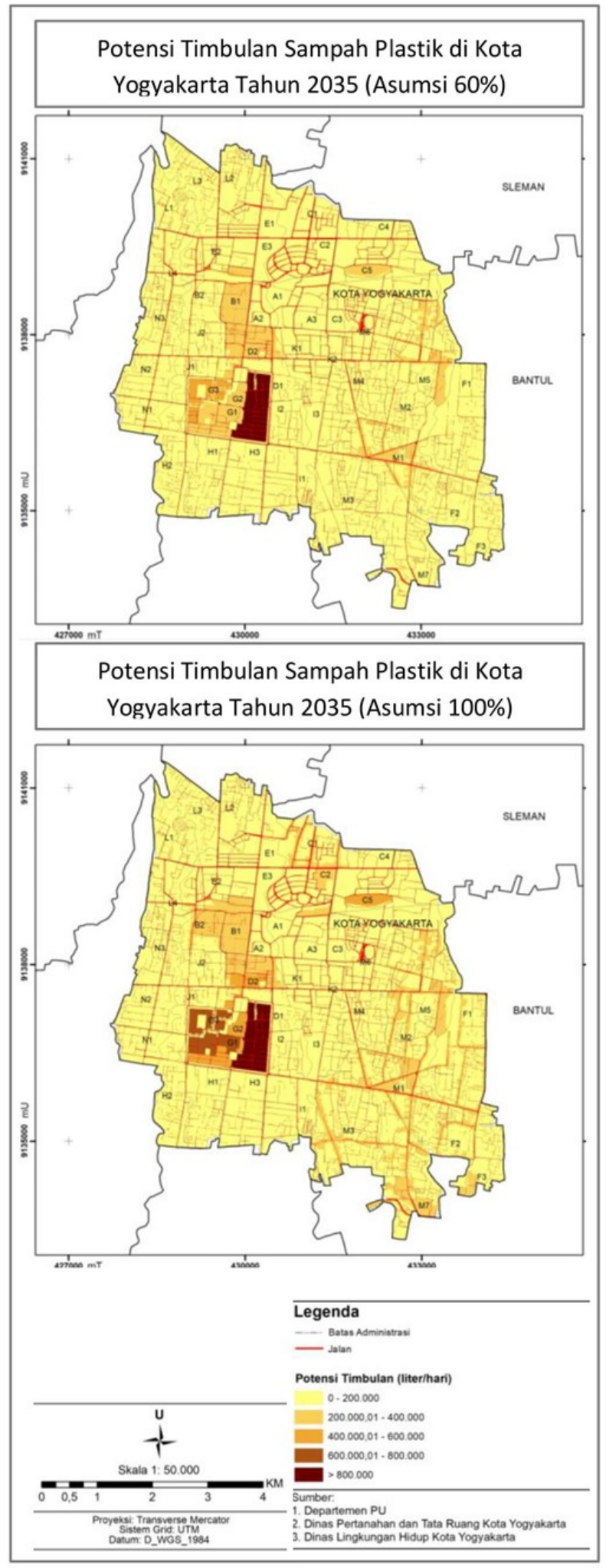

Gambar 2. Peta Potensi Timbulan Sampah Plastik Kota Yogyakarta Tahun 2035 (Asumsi 60\% dan 100\%) (Sumber: Data olahan, 2019) 
Jurnal Pendidikan Geografi:

Kajian, Teori, dan Praktik dalam Bidang Pendidikan dan Ilmu Geografi

Volume 25, Nomor 2, Jun 2020, Hal 88-101

Objek wisata seperti alun-alun pada umumnya memiliki tingkat intensitas kegiatan yang tinggi didalamnya. Objek wisata tersebut memiliki jumlah pengunjung dalam jumlah tinggi setiap hari yang terjadi pada malam hari. pengunjung objek wisata tersebut merupakan warga lokal maupun wisatawan asing. Intensitas kegiatan yang cukup tinggi ini dapat menyebabkan tinggi pula potensi timbulan sampah plastik yang dihasilkan dari kawasan pariwisata pada Blok G1, G2, dan G3. Di sisi lain, objek wisata seperti Kraton Yogyakarta dan Kampung Wisata Taman Sari memiliki tingkat intensitas kegiatan yang cenderung fluktuatif. Objek wisata tersebut akan diramaikan oleh pengunjung apabila sedang dalam musim tertentu seperti libur panjang. Hal ini dikarenakan wisatawan yang berkunjung ke Kraton Yogyakarta dan Kampung Wisata Tamansari sebagian besar berasal dari masyarakat luar Kota Yogyakarta. Oleh karena itu, potensi timbulan sampah plastik yang dihasilkan dari kedua objek wisata tersebut akan meningkat pada kondisi tertentu.

Kota Yogyakarta telah menjadi salah satu tujuan destinasi wisata di Indonesia, dengan wisata berbasis budaya. Jumlah wisatawan yang berkunjung ke Kota Yogyakarta diprediksikan terus meningkat setiap tahunnya. Oleh karena itu, perlu adanya perencanaan dan pengelolaan yang baik sebagai bentuk antisipasi atas dampak negatif yang ditimbulkan dari kegiatan di dalamnya. Kawasan pariwisata dapat dikatakan sebagai pemicu bagi perkembangan kegiatan lainnya, misalnya kegiatan dalam bidang perdagangan dan jasa.

Sampah plastik dengan potensi timbulan yang juga tinggi di Blok G1, G2, dan G3 bersumber dari kawasan perdagangan dan jasa. Kawasan perdagangan dan jasa memiliki perkembangan yang cukup intensif di ketiga wilayah tersebut. Hal ini disebabkan adanya faktor dorongan dari perkembangan kawasan pariwisata di wilayah tersebut sehingga fasilitas perdagangan dan jasa di sekitarnya juga mengalami perkembangan. Perkembangan fasilitas perdagangan dan jasa ditunjukkan melalui keberadaan berbagai macam jenis fasilitas seperti perhotelan atau penginapan sejenis, restoran atau rumah makan sejenis, pusat perbelanjaan, dan lain sebagainya. Rumah warga yang bermukim di wilayah tersebut tidak jarang pula dialihkan fungsinya sebagai fasilitas pelayanan perdagangan dan jasa seperti penginapan atau rumah makan. Tingginya tingkat perkembangan kegiatan perdagangan dan jasa di sebagian Blok G1, G2, dan G3 memicu tingginya timbulan sampah plastik yang dihasilkan dari kegiatan yang bergerak di dalamnya.

Gambar 2 (A) juga menunjukkan bahwa timbulan sampah plastik yang juga tinggi terjadi pada Blok B1, B2, dan D2. Blok B1 merupakan cakupan wilayah Kelurahan Sosromenduran, Blok B2 merupakan cakupan wilayah Kelurahan Pringgokusuman, dan Blok D2 merupakan cakupan wilayah Kelurahan Ngupasan. Namun pada Gambar 2 menunjukkan bahwa Blok B1 tidak memiliki potensi timbulan sampah plastik yang tinggi apabila realisasi rencana tata ruang di wilayah tersebut diasumsi 60 persen. Blok B1, B2, dan D2 memiliki potensi timbulan sampah plastik yang tinggi yang bersumber dari kawasan perdagangan dan jasa.

Kondisi sebenarnya juga menunjukkan bahwa Blok B1, B2, dan D2 memiliki perkembangan yang cukup tinggi terkait bidang perdagangan dan jasa. Hal ini dikarenakan ketiga blok tersebut terletak dekat dengan pusat destinasi wisata Kota Yogyakarta, yakni Kawasan Wisata Malioboro. Kawasan Wisata Maliboro mengalami perkembangan yang cukup pesat dan memiliki intensitas kegiatan yang tinggi setiap harinya. Kawasan Wisata Malioboro selalu diramaikan pengunjung mulai dari pagi hari hingga malam hari. Kondisi tersebut memicu pertumbuhan serta perkembangan fasilitas perdagangan dan jasa di sekitarnya, seperti fasilitas perhotelan dan penginapan sejenis, 
Jurnal Pendidikan Geografi:

Kajian, Teori, dan Praktik dalam Bidang Pendidikan dan Ilmu Geografi

Volume 25, Nomor 2, Jun 2020, Hal 88-101

pusat perbelanjaan, restoran, dan laun sebagainya. Pertumbuhan dan perkembangan fasilitas perdagangan dan jasa di Blok B1, B2, dan D2 bertujuan untuk memenuhi kebutuhan wisatawan yang berasal dari dalam maupun luar Kota Yogyakarta. Adanya peningkatan luas kawasan perencanaan bagi kegiatan perdagangan dan jasa di Blok B1, B2, dan D2 dapat memicu tingginya potensi timbulan sampah plastik yang dihasilkan dari blok kawasan yang bersangkutan. Padahal, pada umumnya sampah yang bersumber dari kawasan perdagangan dan jasa sebagian besar tidak dikelola dengan baik dan langsung berakhir di tempat sampah.

Pengelolaan sampah terutama sampah plastik sangat penting dilakukan pada fasilitas perdagangan dan jasa. Pengelolaan tersebut memerlukan peran semua pihak dari fasilitas perdagangan dan jasa sebagai sumber timbulan sampah plastik itu sendiri. Pengelolaan sampah plastik dapat dilakukan minimal melalui tindakan pemilahan. Peran tersebut harus dimulai dari pengelola tingkat atas yang kemudian diterapkan pula oleh pihak-pihak di bawahnya. Penerapan ini dapat dimulai melalui edukasi dan tindakan persuasif mengenai pemilahan sampah yang kemudian tidak lagi menjadikannya sebagai sebuah kewajiban, melainkan sebagai gaya hidup. Tindakan ini tidak hanya dilakukan oleh pihak pengelola fasilitas perdagangan dan jasa, melainkan juga dipersuasifkan kepada pengunjung atau pelanggan, mengingat jumlah wisatawan di Kota Yogyakarta semakin mengalami peningkatan.

Realisasi rencana dengan asumsi 100 persen (Gambar 2 (B))juga menunjukkan bahwa potensi timbulan sampah plastik di Kota Yogyakarta pada tahun 2035 cukup tinggi terjadi pada Blok C2. Blok C2 merupakan cakupan wilayah Kelurahan Kotabaru. Potensi timbulan sampah cukup tinggi di wilayah tersebut bersumber dari kawasan sarana kesehatan. Pada kondisi sebenarnya, Blok C2 memiliki beberapa fasilitas sarana kesehatan seperti Rumah Sakit Bethesda, Rumah Sakit DKT Dr. Soetarto, dan Hi-Lab Kotabaru. Sampah plastik yang dihasilkan dari fasilitas sarana kesehatan sebagain besar merupakan sampah medis. Sampah medis perlu dilakukan pengelolaan sebelum dibuang langsung ke tempat sampah atau didaur ulang. Hal ini dikarenakan zat kimia yaang terkandung di dalamnya dalam mencemari lingkungan dan berbahaya apabila diproses kembali sebagai bahan baku plastik yang baru. Pengelolaan tersebut harus melibatkan pihak internal fasilitas kesehatan karena peranannya sebagai penyetor sampah yang bersangkutan secara gelondongan kepada pelapak daur ulang.

Potensi timbulan sampah plastik di Kota Yogyakarta tahun 2035 dengan pola memusat juga terjadi pada Blok C5. Blok C5 merupakan cakupan wilayah Kelurahan Demangan. Potensi timbulan sampah plastik cukup tinggi di wilayah tersebut bersumber dari kawasan sarana transportasi. Kondisi tersebut sama halnya dengan Blok M7 yang merupakan cakupan wilayah Kelurahan Giwangan. Blok M7 juga memiliki potensi timbulan sampah yang cukup tinggi dari kawasan sarana transportasinya. Namun, kawasan yang diperuntukkan sebagai sarana transportasi di Blok C5 belum teridentifikasi akan diperuntukkan sebagai sarana transportasi jenis apa. Sedangkan pada Blok M7 menjadi kawasan pengembangan sarana transportasi darat. Contoh fasilitas sarana transportasi yang terdapat di Blok M7 adalah Terminal Giwangan.

Terminal Giwangan pada umumya memiliki tingkat intensitas kegiatan yang cukup tinggi di dalamnya. Hal ini dikarenakan Terminal Giwangan sudah menjadi salah satu terminal bus yang cukup besar di Kota Yogyakarta. Mobilitas transportasi bus melalui terminal tersebut terjadi setiap hari. kondisi tersebut yang dapat memicu adanya timbulan sampah plastik dengan potensi yang cukup tinggi di masa mendatang.

Gambar 2 (B) pada Peta Timbulan Sampah Plastik Kota Yogyakarta Tahun 2035 Asumsi 100 Persen juga menunjukkan adanya pola linear untuk sebaran potensi timbulan 
Jurnal Pendidikan Geografi:

Kajian, Teori, dan Praktik dalam Bidang Pendidikan dan Ilmu Geografi

Volume 25, Nomor 2, Jun 2020, Hal 88-101

sampah plastik di Kota Yogyakarta pada tahun 2035. Pola linear tersebut terjadi di sepanjang jalan utama di Kota Yogyakarta. Potensi timbulan yang cukup tinggi di sepanjang jalan utama Kota Yogyakarta sebagian besar bersumber dari kawasan perdagangan dan jasa. Kawasan perdagangan dan jasa pada umumnya berkembang sangat pesat di sepanjang jalan utama Kota Yogyakarta. Fasilitas-fasilitas perdagangan dan jasa yang memiliki perkembangan yang cukup pesat diantaranya rumah makan, perhotelan, bank, pertokoan, dan pedagang kaki lima (PKL). Kegiatan-kegiatan di dalamnya memiliki tingkat intensitas yang cukup tinggi dan terjadi setiap hari. Kondisi tersebut menjadi salah satu penyebab tingginya timbulan sampah plastik di Kota Yogyakarta.

Hasil penelitian ini menunjukkan bahwa proyeksi mengenai potensi timbulan sampah plastik di Kota Yogyakarta pada masa mendatang sangat dibutuhkan dalam melakukan penanganan terkait dampak dari perkembangan kota. Perkembangan kota yang cukup kompleks dapat memberikan dampak negatif dalam berbagai aspek, salah satunya dampak bagi lingkungan. Dampak lingkungan dapat disebabkan oleh limbah, salah satunya adalah sampah plastik. Sampah plastik dapat memberikan dampak yang serius bagi lingkungan perkotaan karena sampah plastik memiliki sifat yang sulit terurai. Oleh karena itu, apabila sampah plastik tidak mengalami proses pengelolaan dengan baik akan berbahaya bagi lingkungan dan kehidupan masyarakat.

Pengelolaan sampah plastik harus dilakukan mulai dari sumbernya. Apabila sumber timbulan sampah sendiri tidak dilibatkan, maka proses pengelolaan tidak akan berjalan hingga tahap selanjutnya. Pengelolaan sampah plastik dapat dilakukan melalui beberapa langkah, yakni reduce, reuse, recyle, dan disposal (Basriyanta, 2007). Konsep $3 R$ juga dituangkan dalam (PU, 2006) untuk merumuskan kebijakan dan strategi nasional pengembangan sistem pengelolaan sampah. Reduce adalah cara pengelolaan sampah dengan mengurangi penggunaannya. Reuse adalah cara pengelolaan sampah dengan menggunakannya kembali untuk kebutuhan lainnya. Recycle adalah cara pengelolaan sampah dengan memproses kembali sehingga menjadi barang yang memiliki nilai guna. Disposal adalah cara pengelolaan sampah dengan mengolah terlebih dahulu sebelum dibuang langsung ke tempat pembuangan akhir. Namun, salah satu cara yang dapat menciptakan nilai ekonomi dalam pengelolaan sampah plastik adalah melalui proses recycle atau disebut juga sebagai proses daur ulang.

Daur ulang merupakan suatu proses pengolahan kembali terhadap sampah plastik agar kembali memiliki nilai guna sekaligus nilai ekonomi. Proses ini menunjukkan bahwa sampah plastik yang pada awalnya tidak memiliki nilai, namun dapat tercipta nilai ekonomi di dalamnya setelah mengalami beberapa proses pengolahan. Surono dan Ismanto (2013) berpendapat bahwa proses daur ulang sampah plastik bertujuan untuk menghasilkan produk akhir yang kembali memiliki nilai ekonomi atau dapat diperjualbelikan lagi. Daur ulang dianggap sebagai opsi yang layak dalam pengolahan sampah plastik (Bhattacharya, 2018). Adanya daur ulang sampah plastik dapat mengurangi eksploitasi minyak bumi sebagai bahan baku plastik. Namun, proses daur ulang harus melibatkan banyak banyak pihak karena prosesnya yang cukup kompleks.

Bisnis daur ulang limbah plastik melibatkan rantai pasokan bahan daur ulang, yang meliputi konsumen, bank sampah, pemulung, pengumpul limbah skala kecil dan besar, serta pabrik daur ulang (Kristina et al., 2018). Pernyataan tersebut menunjukkan bahwa daur ulang memerlukan beberapa tahapan pemrosesan untuk menghasil produk akhir yang siap dipasarkan kepada konsumen. Pengelolaan sampah plastik melalui proses daur ulang juga harus mendapatkan perhatian dari berbagai pihak, seperti masyarakat, pemerintah, dan pihak swasta. 
Jurnal Pendidikan Geografi:

Kajian, Teori, dan Praktik dalam Bidang Pendidikan dan Ilmu Geografi

Volume 25, Nomor 2, Jun 2020, Hal 88-101

Masyarakat dalam hal ini berperan sebagai penghasil sampah plastik. Penghasil sampah plastik harus memahami cara pengelolaannya melalui proses pemilahan. Hal ini dikarena pemilahan harus dilakukan sejak dari sumber sampah plastik itu sendiri. Tujuannya adalah agar sampah plastik tidak terkontaminasi dengan sampah jenis lainnya. Sampah plastik yang terkontaminasi dengan sampah jenis lainnya akan mengurangi kualitasnya dalam proses pengolahan. Pihak swasta dalam proses daur ulang memiliki peran sebagai pelaku usaha atau pelaku bisnis. Pelaku bisnis memiliki peran yang sangat penting karena posisinya sebagai pemilik modal. Di sisi lain, pemerintah sebagai pembuat kebijakan memiliki peranan penting dalam mewadahi proses daur ulang. Dalam (Perpres, 2017), pemerintah menargetkan penanganan sampah hingga 70 persen dari angka timbulan sampah sebelum keluarnya kebijakan tersebut. Peraturan tersebut diharapkan tidak hanya menjadi wacana, melainkan juga terdapat aksi agar target yang ditetapkan dapat tercapai.

Pencapaian target pemerintah mengenai penangangan sampah plastik dapat disukseskan melalui proses daur ulang yang saat ini sudah banyak dilakukan oleh para pelaku usaha di Kota Yogyakarta. Pemerintah harus memposisikan diri sebagai pihak yang mendukung usaha-usaha tersebut melalui kemudahan proses perizinan usaha hingga insentif dan disinsentif bagi pihak yang terlibat dalam proses daur ulang. Edukasi dan apresiasi juga sangat perlu dilakukan terhadap masyarakat sebagai sumber utama timbulan sampah plastik sekaligus sebagai pemilah sampah tahap pertama.

\section{KESIMPULAN}

Timbulan sampah plastik di Kota Yogyakarta diproyeksi dengan beberapa asumsi. Asumsi tersebut dilakukan atas dasar kemungkinan realisasi perencanaan yang dirumuskan dalam RDTR Kota Yogyakarta Tahun 2015-2035. Peneliti mengasumsikan adanya kemungkinan realisasi perencanaan sebesar 60 persen dan 100 persen. Asumsi realisasi perencanaan $60 \%$ diprediksi dapat menghasilkan timbulan sampah sebesar 9.909.411,18 liter/hari. Sementara asumsi realisasi perencanaan $100 \%$ diprediksi menghasilkan timbulan 16.504.985,03 liter/hari. Kawasan yang memiliki timbulan sampah plastik cukup tinggi adalah kawasan perumahan, cagar budaya, pariwisata, dan kawasan perdagangan dan jasa. Sampah plastik dapat memberikan dampak yang serius bagi lingkungan perkotaan karena sampah plastik memiliki sifat yang sulit terurai. Oleh karena itu, apabila sampah plastik tidak mengalami proses pengelolaan dengan baik akan berbahaya bagi lingkungan dan kehidupan masyarakat. Perkembangan kota yang cukup kompleks juga dapat memberikan dampak bagi lingukungan, salah satunya dapat menyebabkan wilayah tersebut memiliki potensi timbulan sampah dalam volume yang cukup tinggi di masa mendatang.

\section{DAFTAR RUJUKAN}

Adedibu, A. E. (1985). Spatial pattern of solid waste generation of Ilorin-Nigeria. Kluwer Academic Publishers.

Basriyanta. (2007). Memanen sampah. Yogyakarta: Kanisius.

Bhattacharya, R. S. (2018). Challenges and opportunities plastic waste management in India. The Energy and Resources Institute (TERI) Analysis.

Ekawati. (2016). Mengkritisi kebijakan penanganan kantong plastik di Indonesia. Policy Brief: Pusat Penelitian dan Pengembangan Sosial, Ekonomi, Kebijakan, dan Perubahan Iklim, 6.

Jambeck, J., Geyer, R., Wileox, C., Siegler, T., Perryman, M., Andrady, A., et al. (2015). Plastic waste inputs from land into the ocean. Science, 768. 
Jurnal Pendidikan Geografi:

Kajian, Teori, dan Praktik dalam Bidang Pendidikan dan Ilmu Geografi

Volume 25, Nomor 2, Jun 2020, Hal 88-101

Kristina, H., Christiani, A., \& Joniliong, E. (2018). The prospects and challenges of plastics bottle waste recycling in Indonesia. Paper presented at the meeting of the 2nd International Conference on Eco Engineering Development 2018, Alam Sutera Tangerang, Indonesia.

Mulasari, A., Husodo, A. H., \& N., M. (2016). Analisis situasi permasalahan sampah Kota Yogyakarta dan kebijakan penanggulangannya. Jurnal Kesehatan Masyarakat.

Perda. (2015). Paten no. peraturan Daerah Kota Yogyakarta nomor 1 tahun 2015 tentang rencana detail tata ruang Kota Yogyakarta tahun 2015-2035. Yogyakarta.

Perpres. (2017). Paten no. Peraturan Presiden RI nomor 97 tahun 2017 tentang kebijakan dan strategis nasional pengelolaan sampah rumah tangga dan sampah sejenis sampah rumah tangga. Indonesia.

PU. (2006). Paten no. Peraturan Menteri PU nomor 21/PRT/M/2006 tentang pengelolaan sampah. Indonesia.

Rybova, K., \& Burcin, B. (2017). Does spatial dimension matter in waste generation? Case study of Czech municipalities. Paper presented at the meeting of the International Conference Current Trends in Public Sector Research. Czech: researchgate.net.

SNI. (2004). Paten no. SNI 03-1733-2004 tentang tata cara perencanaan lingkungan perumahan di perkotaan. Indonesia.

SNI. (2008). Paten No. SNI-3242-2008 tentang pengelolaan sampah di permukiman. Indonesia.

Surono, U. B., \& Ismanto. (2016). Pengelolaan sampah plastik jenis PP, PET, dan PE menjadi bahan bakar minyak dan karakteristiknya. Jurnal Mekanika dan Sistem Termal, 32-37. 